\title{
PERAMALAN JUMLAH PENDERITA DEMAMBER DARAH DENGUE DI KABUPATEN JOMBANG JAWA TIMUR DENGAN PENDEKATAN FUNGSI TRANSFER SINGLE INPUT
}

\author{
Sediono ${ }^{1} \&$ Tito, $D$
}

\begin{abstract}
Forecasting is an important things in time series analysis, because by obtaining a convenient model that is statictically appropriate. Clearly, that can be used to predict the structure of future data form. Transfer function is one of mathematical model in time series analysis, that can be used to forecasting time index data both univariate and multivariate. Transfer function describes the predictive value of the output series (Yt) based on the value of one or more input series $(\mathrm{Xt})$. The single input transfer function model is a transfer function model that uses one variable as input series $(\mathrm{Xt})$, where each series of both input series and output series must be a stationary time series model, both stationary in the mean and stationary in variant. One of the used transfer function is to govern a model and forecasting of the number of cases dengue fever (Yt) in Kabupaten Jombang, East Java, where the input variable based on data of rainfall $(\mathrm{Xt})$. From the result of this study was obtained that model of transfer function has a equation $\mathrm{Y} t=$ $0,0542 \mathrm{Xt}+(1-0,7309 B)(1+0,6568 B 12)$ with parameter $\omega \mathrm{o}=0.0542, \emptyset 1=$ 0.7309 and $\Phi 12=-0.6568$. From the model, it can be interpreted that the number of dengue sufferers for a particular month was influenced by the rainfall on those month and the months before. According to the model of the transfer function, it can be used to forecast the number of sufferers of dengue fever in Kabupaten Jombang for period next 20 months. After compared between data of forecasting and actual data, there exists equally trend, namely 15 months of 20 month that are forecasted, such that it can be explain that majority $75 \%$ of the results of forecasting in this study are valid.
\end{abstract}

Keywords: forecasting, single input transfer function, stationer point, Dengue fever

\footnotetext{
Abstrak

Peramalan adalah sesuatu hal yang penting dalam analisis runtun waktu, karena dengan diperolehnya sebuah model yang tepat secara statistik, jelas hal tersebut dapat digunakan untuk memprediksi struktur pola data yang akan datang. Fungsi transfer merupakan salah satu model matematis dalam analisis runtun waktu yang dapat digunakan untuk peramalan data indekswaktu baik univariat maupun multivariat. Fungsi transfer menggambarkan nilai prediksi dari output series $(\mathrm{Yt})$ berdasarkan nilai satu atau lebih input series $(\mathrm{Xt})$. Model fungsi transfer single input adalah model fungsi transfer yang menggunakan satu variabel sebagai input series $(\mathrm{Xt})$, dimana

${ }^{1}$ Prodi StatistikaUniversitasAirlangga

email : sediono101@gmail.com
} 
masing-masing series baik input series maupun output series keduanya harus sama-sama merupakan model runtun waktu yang stasioner, baik stasioner dalam mean maupun stasioner dalam varian. Salah satu penggunaan model fungsi transfer ini adalah untuk pembuatan model dan peramalan jumlah kasus demam berdarah dengue (Yt) di Kabupaten Jombang Jawa Timur, dengan variabel inputnya berdasarkan data curah hujan $(\mathrm{Xt})$. Dari hasil penelitian diperoleh model fungsi transfer yang memiliki persamaan $\mathrm{Y} t=0,0542 \mathrm{X} t+(1-0,7309 B)(1+0,6568 B 12) a t$, dengan parameter $\omega 0=0,0542, \emptyset 1=0,7309$, dan $\Phi 12=-0,6568$. Dari model tersebut dapat diinterpretasikan bahwa jumlah penderita demam berdarah dengue pada suatu bulan dipengaruhi curah hujan pada bulan itu, dan dipengaruhi oleh beberapa gangguan pada bulan-bulan sebelumnya. Selanjutnya berdasarkan model fungsi transfer tersebut dapat digunakan untuk peramalan jumlah penderita demam berdarah dengue di Kabupaten Jombang untuk periode 20 bulan kedepan. Setelah dilakukan perbandingan antara data hasil peramalan dengan data aktual, terdapat kesamaan trend yaitu sejumlah 15 bulan dari 20 bulan yang diramalkan, sehingga dapat dijelaskan bahwa sebagian besar yaitu $75 \%$ dari hasil peramalan dalam penelitian ini adalah valid.

Kata Kunci : Peramalan, Fungsi transfer single input, stasioner, Demam Berdarah Dengue.

\section{PENDAHULUAN}

Analisis Time Series atau yang sering disebut runtun waktu merupakan suatu metode analisis kuantitatif yang mempertimbangkan waktu, dimana data dikumpulkan secara periodik berdasarkan urutan waktu untuk menentukan pola data masa lampau yang telah dikumpulkan secara teratur [1]. Dalam aplikasinya telah dikembangkan suatu metode analisis runtun waktu yaitu fungsi transfer. Model fungsi transfer merupakan salah satu model analisis runtun waktu yang sering digunakan untuk proses peramalan data runtun waktu yang melibatkan dua variabel, yakni variabel input dan variabel output. Secara umum konsep fungsi transfer terdiri dari deret output $\left(Y_{t}\right)$, deret input $\left(X_{t}\right)$, dan seluruh pengaruh lain yang disebut dengan gangguan $\left(n_{t}\right)$ [4]. Fungsi transfer dapat diaplikasikan di berbagai bidang termasuk bidang kesehatan, seperti pada peramalan jumlah penderita demam berdarah dengue (DBD). Kabupaten Jombang, tercatat sebagai salah satu kota/kabupaten dengan jumlah kasus DBD tertinggi di Jawa Timur. Sepanjang tahun 2016, jumlah kasus DBD di Kabupaten Jombang mencapai lebih dari 700 kasus [2].Faktor cuaca seperti curah hujan serta kondisi geografis Kabupaten Jombang yang berada di dataran tropis menciptakan kondisi lingkungan dengan suhu dan kelembapan yang sesuai untuk memicu perkembangbiakan nyamuk. Penelitian Sihombing [3] menyatakan bahwa ada hubungan yang signifikan antara curah hujan dengan kejadian DBD. Namun antara keduanya perlu dilihat hubungan secara periodik guna dapat meramalkan kejadian DBD tersebut berdasarkan curah hujan sebagai antisipasi kejadian di masa mendatang. Oleh karena itu, fungsi transfer adalah metode analisis yang memungkinkan untuk digunakan dalam memodelkan serta menjelaskan hubungan dari keduanya untuk meramalkan kejadian DBD. Dari penelitian ini akan dibahas pemodelan hubungan antara jumlah kasus DBD dengan curah hujan di Kabupaten Jombang beserta peramalannya dengan pendekatan metode fungsi transfer

\section{METODE PENELITIAN}

Pada bagian ini akan dijelaskan beberapa tahapan antara lain terkait sumber data, variabel penelitian dan prosedur penelitian.

\subsection{Sumber Data}


Data yang digunakan dalam penelitian ini merupakan data sekunder time series per bulan tentang jumlah penderita Demam Berdarah Dengue (DBD) dan rata-rata curah hujan di Kabupaten Jombang. Data diambil pada periode bulan Januari 2009 sampai dengan bulan Agustus 2017. Pengambilan data dilakukan di Dinas Kesehatan Kabupaten Jombang dan Stasiun Meteorologi Dinas Pertanian Kabupaten Jombang, Jawa Timur.

\subsection{VariabelPenelitian}

Variabel yang digunakan dalam penelitian ini adalah deret output $\left(Y_{t}\right)$ yaitu jumlah penderita DBD dan deret input $\left(X_{t}\right)$ yaitu curah hujan. Data deret output dan deret input adalah berupa data time series per bulan dengan periode waktu bulan Januari 2009 sampai dengan bulan Agustus 2017.

\subsection{Prosedur Penelitian} berikut :

Berdasarkan uraian diatas langkah-langkah dalam penelitian ini adalah sebagai

1. Melihat karakteristik data jumlah penderita DBD dan curah hujan di Kabupaten Jombang dengan mendeskripsikan nilai minimum, maksimum, mean, dan simpangan baku.

2. Membuat pemodelan fungsi transfer hubungan antara curah hujan dengan jumlah kasus penderita DBD di Kabupaten Jombang dengan langkah-langkah sebagai berikut:

a. Mempersiapkan data deret output dan data deret input dengan melihat stasioneritas masing-masing berdasarkan plot ACF, dan plot PACF. Tahap ini mengidentifikasi apakah deret output dan deret input sudah stasioner baik dalam rataan ataupun dalam varian.

b. Melakukan identifikasi model ARIMAuntuk deret output dan input berdasarkan plot ACF, dan plot PACF dengan metode estimasi parameterMaximum Likelihood Estimation (MLE). Serta melakukan uji diagnostik uji $Q$ untuk mengetahui apakah suatu seriessudah memenuhi proses white noise.

c. $\quad$ Prewhitening deret input (suhu udara) dan deret output (jumlah penderita DBD) untuk menghilangkan seluruh pola yang diketahui supaya yang tertinggal hanya white noise.

d. Perhitungan korelasi silang (cross correlation) dan autokorelasi deret input dan output yang telah white noise untuk melihat hubungan antara keduanya.

e. Penaksiran langsung bobot respon implus dan penetapan $(r, s, b)$ untuk model Fungsi Transfer yang menghubungkan deret input dan output.

f. Penaksiran model ARIMA deret gangguan $\left(n_{\mathrm{t}}\right)$ berdasarkan perhitungan autokorelasi (ACF) serta autokorelasi parsial (PACF) untuk deret ini.

g. Penetapan $\left(p_{n}, q_{n}\right)$ untuk model ARIMA $\left(p_{n}, 0, q_{n}\right)$ dari deret noise atau gangguan $\left(n_{t}\right)$.

h. Estimasi parameter-parameter model dari model fungsi transfer menggunakan metode MLE (Maximum Likelihood Estimator).

i. Pemilihan model terbaik berdasarkan nilai AIC, SBC, dan MSE.

j. Penggunaan model fungsi transfer untuk peramalan. 


\section{Sediono \& Tito, D}

3. Melakukan peramalan jumlah kasus penderita DBD di Kabupaten Jombang melalui model fungsi transfer yang telah diperoleh.

\section{HASIL DAN PEMBAHASAN}

a. Karakteristik Data

Hasil statistika deskriptif dari data jumlah penderita demam berdarah dengue

(DBD) (Yt) dan data curah hujan (Xt) dapat dilihat pada Tabel 1 sebagai berikut:

Tabel 1. Statistika Deskriptif Deret Output dan Deret Input

\begin{tabular}{|l|l|l|r|r|r|r|}
\hline Variabel & Label & \multicolumn{1}{l|}{ N } & \multicolumn{1}{l|}{ Mean } & Dev & Minimum & Maximum \\
\hline $\mathrm{Y}$ & DBD & 84 & 37.95 & 30.88 & 9.0 & 162.0 \\
\hline $\mathrm{X}$ & Curah hujan & 84 & 163.89 & 136.39 & 1.0 & 453.6 \\
\hline
\end{tabular}

b. Pemodelan Fungsi Trasfer Single Input

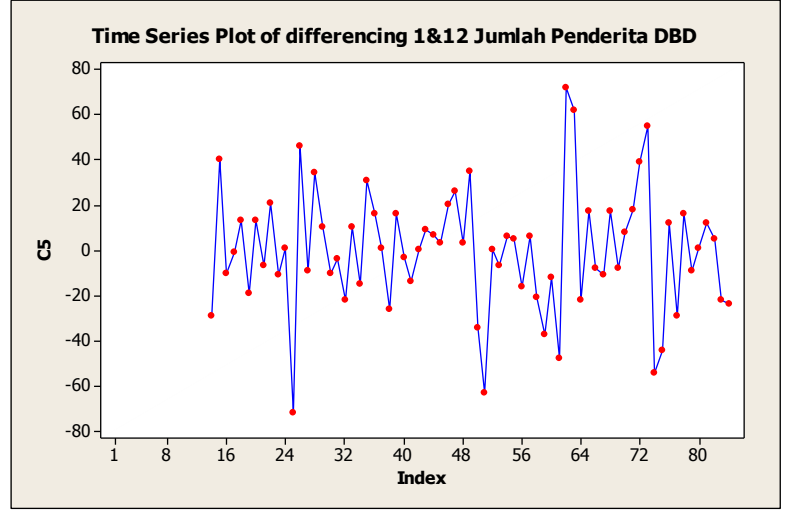

Gambar 1. Plot Time Series Data Jumlah Kasus Penderita DBD Kabupaten Jombang tahun 2009-2015 yang Telah Stasioner

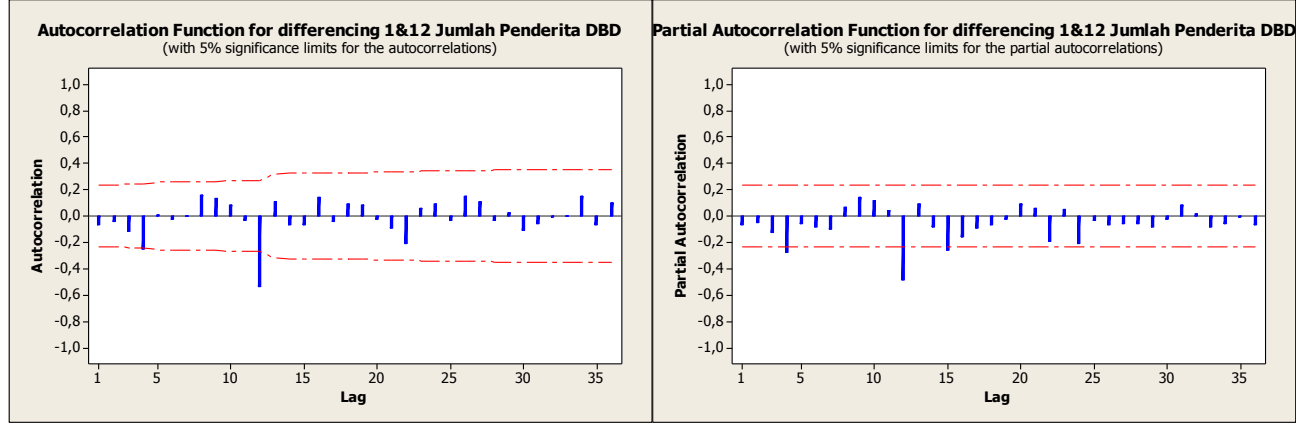

Gambar 2. Plot ACF dan PACF Differencing 1 dan 12 Data Jumlah Kasus Penderita DBD Kabupaten Jombang tahun 2009-2015 yang Telah Stasioner

Gambar 1 menunjukkan pola stasioner pada data yang berfluktuasi pada rata-rata dan varian yang konstan. Gambar 2, Pada plot ACF menunjukkan terdapat lag yang signifikan yaitu pada lag 12. Begitu juga pada plot PACF terdapat beberapa lag yang signifikan yaitu pada lag ke 12. Pola ACF dan PACF menunjukkan adanya pola musiman sehingga dapat ditentukan model-model tentatif ARIMA deret output. 
Sediono \& Tito, D

Tabel 2. Uji Diagnostik P-Value, AIC, dan SBC Model ARIMA Deret Output

\begin{tabular}{|c|c|c|c|c|c|}
\hline \multirow{2}{*}{ No } & ARIMA & Estimasi & P Valu & \multirow{2}{*}{ AIC } & \multirow{2}{*}{$\mathrm{SBC}$} \\
\hline & $(\mathrm{p}, \mathrm{d}, \mathrm{q})(\mathrm{p}, \mathrm{d}, \mathrm{q})^{12}$ & Parameter & P-Value & & \\
\hline 1 & $(0,1,0)(1,1,0)^{12}$ & -0.677 & 0.0001 & 635.966 & 638.228 \\
\hline 2 & $(0,1,0)(0,1,1)^{12}$ & 0.999 & 0.9914 & 630.318 & 632.581 \\
\hline \multirow{2}{*}{3} & \multirow{2}{*}{$(0,1,0)(1,1,1)^{12}$} & 0.392 & 0.0312 & \multirow{2}{*}{636.593} & \multirow{2}{*}{641.119} \\
\hline & & -0.409 & 0.0326 & & \\
\hline
\end{tabular}

Tabel 3. Uji Diagnostik P-Value, AIC, dan SBC Model ARIMA Deret Output

\begin{tabular}{|c|c|c|c|c|c|}
\hline \multirow{2}{*}{ No } & ARIMA & \multicolumn{4}{|c|}{ P-Value Ljung-Box } \\
\cline { 2 - 6 } & $(\mathrm{p}, \mathrm{d}, \mathrm{q})(\mathrm{p}, \mathrm{d}, \mathrm{q})^{12}$ & 6 & 12 & 18 & 24 \\
\hline $\mathbf{1}$ & $(\mathbf{0 , 1 , 0})(\mathbf{1 , 1 , 0})^{\mathbf{1 2}}$ & $\mathbf{0 . 1 0 3 5}$ & $\mathbf{0 . 2 2 3 6}$ & $\mathbf{0 . 3 6 0 3}$ & $\mathbf{0 . 1 8 4 6}$ \\
\hline 2 & $(0,1,0)(0,1,1)^{12}$ & 0.2109 & 0.4557 & 0.5426 & 0.2558 \\
\hline 3 & $(0,1,0)(1,1,1)^{12}$ & 0.0559 & 0.2844 & 0.4093 & 0.2127 \\
\hline
\end{tabular}

Berdasarkan Tabel 2 dan Tabel 3 maka diperoleh model terbaik degan memenuhi prinsip parsimony yaitu signifikansi parameter, kesalahan minimum dan syarat white noise untuk deret output yaitu model ARIMA $(0,1,0)(1,1,0)^{12}$.

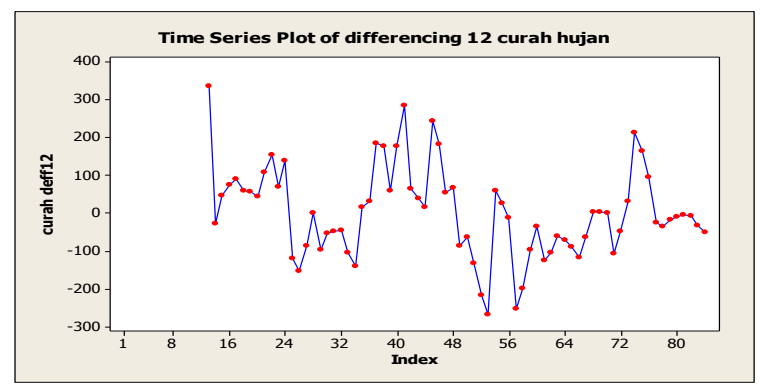

Gambar 3. Plot Time Series Data Curah Hujan Kabupaten Jombang tahun 2009-2015 yang telah Stasioner

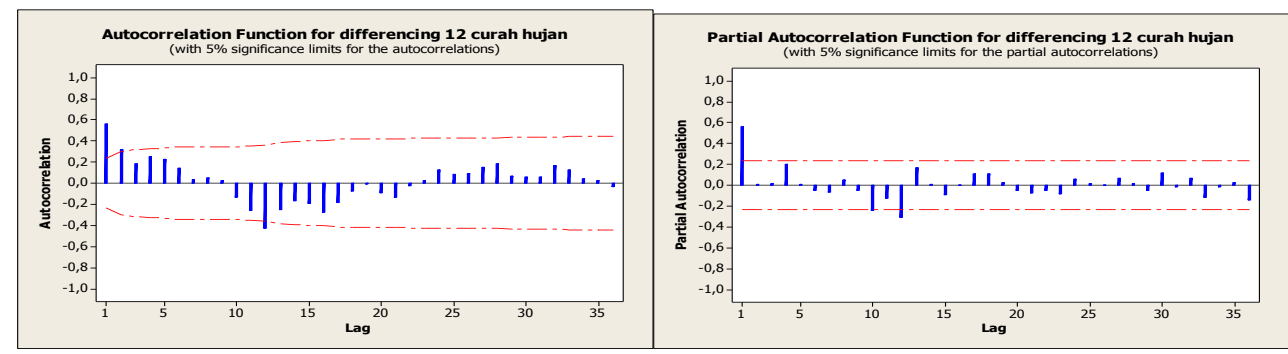

Gambar 4. Plot ACF dan PACF Differencing 12 Data Curah Hujan Kabupaten Jombang tahun 2009-2015 yang telah Stasioner

Berdasarkan Gambar 3 pola stasioner ditunjukkan pada data yang berfluktuasi pada rata-rata dan varian yang konstan. Plot ACF dan PACF pada Gambar 4 menunjukkan lag yang signifikan yaitu lag 1 dan lag 12 yang melewati garis signifikan yang berarti 


\section{Sediono \& Tito, D}

mengandung model ARIMA musiman dan ARIMA non-musiman. Selanjutnya dari plot ACF dan PACF dapat ditentukan model-model tentatif ARIMA deret output.

Tabel 4. Uji Diagnostik P-Value, AIC, dan SBC Model ARIMA Deret Input

\begin{tabular}{|c|c|c|c|c|c|}
\hline \multirow{2}{*}{ No } & ARIMA & \multirow{2}{*}{$\begin{array}{c}\text { Estimasi } \\
\text { Parameter }\end{array}$} & \multirow{2}{*}{ P-Value } & \multirow{2}{*}{ AIC } & \multirow{2}{*}{ SBC } \\
\hline & $(p, d, q)(p, d, q)^{12}$ & & & & \\
\hline \multirow{2}{*}{1} & \multirow{2}{*}{$(1,0,0)(1,1,0)^{12}$} & 0.5823 & 0.0001 & \multirow{2}{*}{852.665} & \multirow{2}{*}{857.218} \\
\hline & & -0.4553 & 0.0001 & & \\
\hline 2 & $(1,0,0)(0,1,1)^{12}$ & 0.6199 & 0.0001 & 852.404 & 856.957 \\
\hline \multirow[t]{2}{*}{3} & \multirow{2}{*}{$(0,0,1)(1,1,0)^{12}$} & -0.4760 & 0.0001 & \multirow[t]{2}{*}{858.962} & \multirow[t]{2}{*}{863,516} \\
\hline & & -0.4675 & 0.0001 & & \\
\hline \multirow[t]{2}{*}{4} & \multirow{2}{*}{$(0,0,1)(0,1,1)^{12}$} & -0.4309 & 0.0001 & \multirow[t]{2}{*}{858.549} & \multirow[t]{2}{*}{863.102} \\
\hline & & 0.6572 & 0.0001 & & \\
\hline
\end{tabular}

Tabel 5. Uji Diagnostik P-Value, AIC, dan SBC Model ARIMA Deret Input

\begin{tabular}{|c|c|c|c|c|c|}
\hline \multirow{2}{*}{ No } & ARIMA & \multicolumn{4}{|c|}{ P-Value Ljung-Box } \\
\cline { 2 - 6 } & $(\mathrm{p}, \mathrm{d}, \mathrm{q})(\mathrm{p}, \mathrm{d}, \mathrm{q})^{12}$ & 6 & 12 & 18 & 24 \\
\hline 1 & $(1,0,0)(1,1,0)^{12}$ & 0.4426 & 0.7187 & 0.8924 & 0.9782 \\
\hline $\mathbf{2}$ & $\left(\mathbf{1 , 0 , 0}(\mathbf{0 , 1}, \mathbf{1})^{12}\right.$ & $\mathbf{0 . 2 7 4 6}$ & $\mathbf{0 . 5 8 2 7}$ & $\mathbf{0 . 7 9 9 7}$ & $\mathbf{0 . 8 5 8 1}$ \\
\hline 3 & $(0,0,1)(1,1,0)^{12}$ & 0.0028 & 0.0347 & 0.1812 & 0.4631 \\
\hline 4 & $(0,0,1)(0,1,1)^{12}$ & 0.0016 & 0.0221 & 0.1280 & 0.2859 \\
\hline
\end{tabular}

Berdasarkan Tabel 4 dan Tabel 5 maka diperoleh model terbaik degan memenuhi prinsip parsimony yaitu signifikansi parameter, kesalahan minimum dan syarat white noise untuk deret input yaitu model ARIMA $(1,0,0)(0,1,1)^{12}$.

Jika deret output dan deret input telah stasioner dalam rata-rata maupun varian, maka selanjutnya dilakukan prewhitening berdasarkan model ARIMA terbaik pada deret input $\left(\mathrm{X}_{\mathrm{t}}\right) \cdot$ Model ARIMA $(1,0,0)(0,1,1)^{12}$ deret input $\left(\mathrm{X}_{\mathrm{t}}\right)$ adalah:

$$
(1-0.5598 B)\left(1-B^{12}\right) X_{t}=\left(1-0.6199 B^{12}\right) \alpha_{t}
$$

Dengan mengubah operator backward shift menjadi bentuk semulamaka persamaan (1) dapat dituliskan:

$$
X_{t}-X_{t-12}-0.5598 X_{t-1}+0.5598 X_{t-13}=\alpha_{t}-0.6199 \alpha_{t-12}
$$

Selanjutnya mengubah persamaan (2) ke bentuk deret white noise $\alpha_{\mathrm{t}}$ menjadi:

$$
\alpha_{t}=X_{t}-X_{t-12}-0.5598 X_{t-1}+0.5598 X_{t-13}+0.6199 \alpha_{t-12}
$$

untuk deret $\beta_{\mathrm{t}}$ diperoleh persamaan sebagai berikut:

$$
\beta_{t}=Y_{t}-Y_{t-12}-0.5598 Y_{t-1}+0.5598 Y_{t-13}+0.6199 \alpha_{t-12}
$$

Selanjutnya dari hasil prewhitening deret input $\left(\alpha_{t}\right)$ yang white noise dan deret hasil prewhitening deret output $\left(\beta_{\mathrm{t}}\right)$ dibuat plot korelasi silang (CCF) untuk menentukan orde $(\mathrm{b}, \mathrm{r}, \mathrm{s})$. 
Sediono \& Tito, D

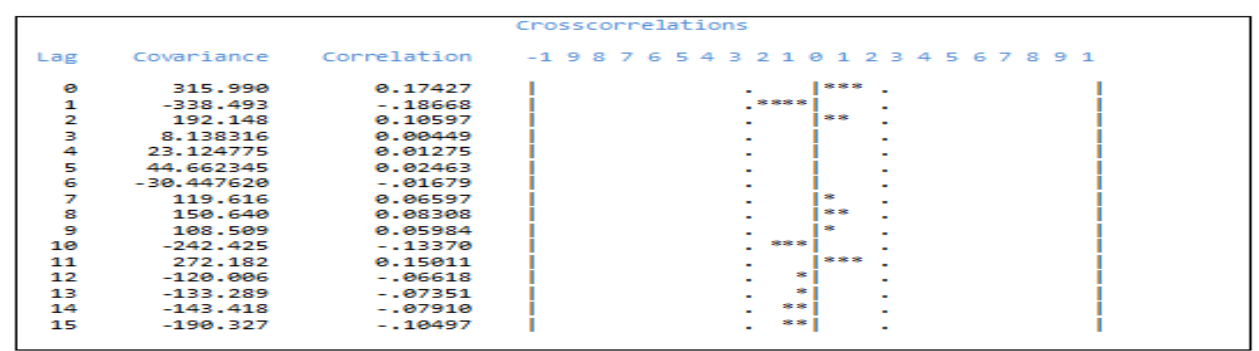

Gambar 5. Plot Korelasi Silang(CCF) Antara $\alpha_{\mathrm{t}}$ dan $\beta_{\mathrm{t}}$

Dilihat dari plot CCF pada Gambar 5 kemunculan lag tertinggi ada pada lag 1 yang berarti orde $b$ adalah 1. Pada plot CCF pola menurun terjadi setelah lag orde $b$, yang artinya orde $\mathrm{s}$ adalah 0 . setelah lag orde $\mathrm{b}$ terjadi pola menurun langsung mendekati nol sehingga orde $\mathrm{r}$ adalah 0 . Selanjutnya dilakukan overfitting model fungsi transfer awal orde (b,s,r) dengan membuat model-model tentatif lainnya.

Tabel 6. Nilai P-Value, AIC, SBC, dan MSE Model Fungsi Transfer Awal

\begin{tabular}{|c|c|c|c|c|}
\hline Model & $\begin{array}{c}\text { Estimasi } \\
\text { Parameter }\end{array}$ & P-Value & AIC & SBC \\
\hline $\mathrm{b}=0, \mathrm{~s}=\mathbf{0}, \mathrm{r}=\mathbf{0}$ & 0.08264 & 0.0124 & 710.297 & 712.574 \\
\hline \multirow{2}{*}{$\mathrm{b}=0, \mathrm{~s}=1, \mathrm{r}=0$} & 0.09591 & 0.0283 & \multirow{2}{*}{702.279} & \multirow{2}{*}{706.804} \\
\hline & 0.00096 & 0.9814 & & \\
\hline $\mathrm{b}=1, \mathrm{~s}=0, \mathrm{r}=0$ & 0.05250 & 0.1247 & 705.061 & 707.324 \\
\hline
\end{tabular}

Karena dari model tentatif hanya terdapat satu model dengan estimasi parameter yang signifikan maka dapat disimpulkan bahwa model terbaik untuk fungsi transfer awal dimiliki oleh model orde $(0,0,0)$ dengan nilai $\omega_{0}=0.08264$. Dari model fungsi transfer awal dapat dibuat model:

$$
y_{t}=0.08264 x+n_{t}(5)
$$

dengan $\mathrm{n}_{\mathrm{t}}$ adalah deret gangguan fungsi transfer. Setelah ditentukan model fungsi transfer awal selanjutnya adalah melakukan proses identifikasi model ARIMA untuk deret gangguan $\left(\mathrm{n}_{\mathrm{t}}\right)$.

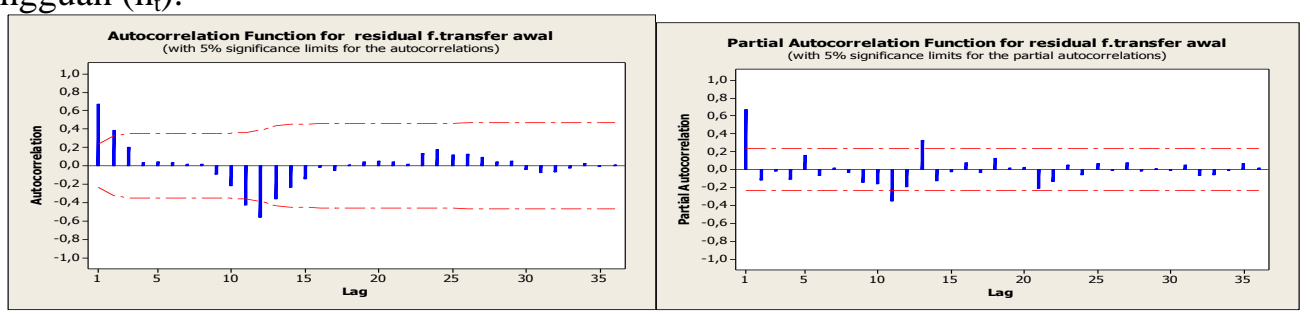

Gambar 6. Plot ACF dan PACF Hasil Deret Gangguan $\left(n_{t}\right)$

Dari plot ACF dan PACF selanjutnya dapat ditentukan model tentatif deret gangguan $\left(n_{t}\right)$ berdasarkan model fungsi transfer awal untuk mendapatkan model fungsi transfer terbaiknya.

Tabel 7. Uji Diagnostik P-Value, AIC, dan SBC Model Fungsi Transfer 
Sediono \& Tito, D

\begin{tabular}{|c|c|c|c|c|c|c|}
\hline No & $\begin{array}{c}\text { Orde } \\
(\mathrm{b}, \mathrm{r}, \mathrm{s})\end{array}$ & $\frac{\text { ARIMA }}{(\mathrm{p}, \mathrm{d}, \mathrm{q})(\mathrm{p}, \mathrm{d}, \mathrm{q})^{12}}$ & $\begin{array}{c}\text { Estimasi } \\
\text { Parameter }\end{array}$ & P-Value & AIC & SBC \\
\hline \multirow{3}{*}{1} & \multirow{3}{*}{$(0,0,0)$} & \multirow{3}{*}{$(1,0,0)(0,0,1)^{12}$} & 0.9997 & 0.9957 & \multirow{3}{*}{626.653} & \multirow{3}{*}{633.484} \\
\hline & & & 0.6816 & 0.0001 & & \\
\hline & & & 0.0441 & 0.0330 & & \\
\hline \multirow{3}{*}{2} & \multirow{3}{*}{$(\mathbf{0 , 0 , 0 )}$} & \multirow{3}{*}{$(1,0,0)(1,0,0))^{12}$} & 0.7309 & 0.0001 & \multirow{3}{*}{634.248} & \multirow{3}{*}{641.078} \\
\hline & & & -0.6568 & 0.0001 & & \\
\hline & & & 0.0542 & $\mathbf{0 . 0 2 3 3}$ & & \\
\hline \multirow{3}{*}{3} & \multirow{3}{*}{$(0,0,0)$} & \multirow{3}{*}{$(0,0,1)(0,0,1)^{12}$} & -0.6085 & 0.0001 & \multirow{3}{*}{640.103} & \multirow{3}{*}{646.933} \\
\hline & & & 0.9996 & 0.9940 & & \\
\hline & & & 0.0472 & 0.0232 & & \\
\hline
\end{tabular}

Tabel 8. Uji Diagnostik Ljung-Box Model Fungsi Transfer

\begin{tabular}{|c|c|c|c|c|c|c|}
\hline \multirow{2}{*}{ No } & \multirow{2}{*}{$\begin{array}{c}\text { Orde } \\
\end{array}$} & (b,r,s) & ARIMA & \multicolumn{4}{|c|}{ P-Value Ljung-Box } \\
\cline { 3 - 7 } & $(0,0,0)$ & $(\mathrm{p}, \mathrm{d}, \mathrm{q})(\mathrm{p}, \mathrm{d}, \mathrm{q})^{12}$ & 6 & 12 & 18 & 24 \\
\hline 1 & $(1,0,0)(0,0,1)^{12}$ & 0.4624 & 0.4724 & 0.6312 & 0.3993 \\
\hline $\mathbf{2}$ & $\mathbf{( 0 , 0 , 0 )}$ & $(\mathbf{1 , 0 , 0})(\mathbf{1 , 0 , 0})^{12}$ & $\mathbf{0 . 3 0 1 3}$ & $\mathbf{0 . 3 6 1 3}$ & $\mathbf{0 . 5 9 0 8}$ & $\mathbf{0 . 4 3 7 3}$ \\
\hline 3 & $(0,0,0)$ & $(0,0,1)(0,0,1)^{12}$ & 0.8269 & 0.9150 & 0.8430 & 0.5698 \\
\hline
\end{tabular}

Berdasarkan hasil tersebut diperoleh model fungsi transfer terbaik yaitu model fungsi transfer orde $(0,0,0)$ dengan model deret gangguan $\operatorname{ARIMA}(1,0,0)(1,0,0)^{12}$ dengan nilai-nilai parameter yaitu $\omega_{0}=0.0542, \emptyset_{1}=0.7309$, dan $\Phi_{1}=-0.6568$. Dari orde-orde yang sudah ditentukan dalam model fungsi transfer didapatkan persamaan model sebagai berikut:

$$
y_{t}=0.0542 x_{t}+\frac{1}{(1-0.7309 B)\left(1+0.6568 B^{12}\right)} a_{t}
$$

Dari model fungsi transfer yang sudah didapatkan selanjutnya adalah memastikan bahwa residual dari hasil pemodelan memenuhi asumsi kenormalan. Dilakukan uji kenormalan menggunakan uji statistik Jarque Bera. Dengan hipotesis sebagai berikut :

$H_{0}$ : Residual berdistribusi normal

$H_{l}$ : Residual tidak berdistribusi normal

Daerah Kritis: Tolak $H_{0}$, jika JB $>\chi_{0.05,2}^{2}(5.991)$

Hasil uji statistik:

$$
J B=\frac{n}{6}\left(S^{2}+\frac{1}{4}(K-3)^{2}\right)=\frac{72}{6}\left((-0.1414)^{2}+\frac{1}{4}(2.5830-3)^{2}\right)=0.76163
$$

Keputusan: $\operatorname{JB}(0.76163)<\chi_{0.05,2}^{2}(5.991)$, maka $H_{0}$ diterima.

Kesimpulan: residual berdistribusi normal.

\section{c. Hasil Peramalan}

Setelah dilihat bahwa model fungsi transfer telah memenuhi asumsi kenormalan maka sudah dapat dilakukan peramalan berdasarkan model fungsi transfer single input dengan persamaan

$$
\begin{aligned}
Y_{t}= & 0.0542 X_{t}-0.0396 X_{t-1}+0.0356 X_{t-12^{-}} 0.0262 X_{t-13}+0.7309 Y_{t-1^{-}} 0.6568 Y_{t-12} \\
& -0.48 Y_{t-13}+a_{t}
\end{aligned}
$$

Dari persamaan 7 dilakukan peramalan untuk 20 bulan kedepan dengan hasil: 
Sediono \& Tito, D

Tabel 9. Hasil Peramalan Jumlah Penderita DBD di Jombang Selama 20 Tahun

\begin{tabular}{|c|c|c|c|c|c|c|}
\hline Periode & Tahun & Bulan & $\begin{array}{c}\text { Hasil } \\
\text { Ramalan }\end{array}$ & Trend & $\begin{array}{c}\text { Data } \\
\text { Aktual }\end{array}$ & Tren \\
\hline 61 & 2016 & Januari & 95 & Naik & 250 & Naik \\
\hline 62 & 2016 & Februari & 77 & Turun & 202 & Turun \\
\hline 63 & 2016 & Maret & 51 & Turun & 88 & Turun \\
\hline 64 & 2016 & April & 33 & Turun & 73 & Turun \\
\hline 65 & 2016 & Mei & 33 & Turun & 39 & Turun \\
\hline 66 & 2016 & Juni & 29 & Turun & 23 & Turun \\
\hline 67 & 2016 & Juli & 19 & Turun & 23 & - \\
\hline 68 & 2016 & Agustus & 19 & - & 54 & Naik \\
\hline 69 & 2016 & September & 21 & Naik & 89 & Naik \\
\hline 70 & 2016 & Oktober & 34 & Naik & 76 & Turun \\
\hline 71 & 2016 & November & 46 & Naik & 121 & Naik \\
\hline 72 & 2016 & Desember & 85 & Naik & 105 & Turun \\
\hline 73 & 2017 & Januari & 134 & Naik & 126 & Naik \\
\hline 74 & 2017 & Februari & 91 & Turun & 61 & Turun \\
\hline 75 & 2017 & Maret & 49 & Turun & 34 & Turun \\
\hline 76 & 2017 & April & 39 & Turun & 11 & Turun \\
\hline 77 & 2017 & Mei & 31 & Turun & 17 & Naik \\
\hline 78 & 2017 & Juni & 35 & Naik & 18 & Naik \\
\hline 79 & 2017 & Juli & 20 & Turun & 2 & Turun \\
\hline 80 & 2017 & Agutus & 21 & Naik & 6 & Naik \\
\hline
\end{tabular}

Berdasarkan Tabel 9 hasil peramalan tentunya tidak akan sama persis, akan tetapi untuk melihat ketepatan peramalan dapat dilihat kesamaan fluktuasi atau trend data dari waktu ke waktu untuk data hasil peramalan dan data aktualnya. Pada peramalan 20 bulan ke depan pada tabel terdapat 15 kesamaan trend yang artinya $75 \%$ data hasil peramalan adalah valid. Selebihnya untuk membandingkan data hasil prediksi dengan data aktual dapat dibuat suatu plot bersama.

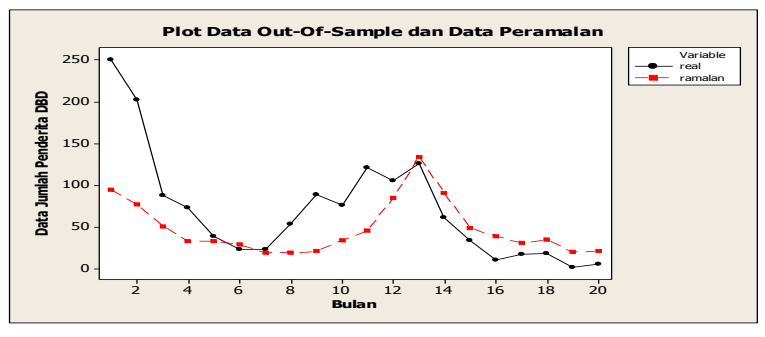

Gambar 7. Plot Data Out-of-Sample dan Data Hasil Peramalan

Pada Gambar 7 terlihat bahwa hasil peramalan jauh dengan data aktualnya pada awal tahun 2016, disebabkan karena terjadinya jumlah penderita demam berdarah dengue (DBD) dengan nilai ekstrim yaitu pada bulan Januari dan Februari tahun 2016 untuk data aktual. Akan tetapi untuk periode-periode berikutnya data hasil peramalan cukup mendekati data aktual.

\section{KESIMPULAN DAN SARAN}

\subsection{Kesimpulan}

Berdasarkan hasil dan pembahasan pada penelitian ini dapat diberikan kesimpulan sebagai berikut: 
1. Data jumlah kasus penderita demam berdarah dengue (DBD) di Kabupaten Jombang pada tahun 2009-2015 memiliki karakteristik yaitu rata-rata jumlah penderita per bulan sebanyak 38 orang penderita dengan simpangan baku 32 orang penderita, serta jumlah kasus tertinggi dengan jumlah 162 orang penderita dan jumlah kasus terendah dengan jumlah 9 orang penderita. Sedangkan untuk data curah hujan di Kabupaten Jombang pada tahun 2009-2015 memiliki karakteristik yaitu rata-rata curah hujan $136.39 \mathrm{~mm}$ dengan simpangan baku $136.39 \mathrm{~mm}$, serta curah hujan tertinggi mencapai 453.6mm dan curah hujan terendah adalah $1 \mathrm{~mm}$.

2. Model terbaik yang digunakan untuk meramalkan jumlah kasus penderita demam berdarah dengue (DBD) di Kabupaten Jombang adalah model fungsi transfer single input berdasarkan kondisi curah hujan di Kabupaten Jombang dengan persamaan model:

$$
y_{t}=0.0542 x_{t}+\frac{1}{(1-0.7309 B)\left(1+0.6568 B^{12}\right)} a_{t}
$$

3. Dari model fungsi transfer untuk jumlah penderita demam berdarah dengue (DBD) di Kabupaten Jombang dilakukan peramalan untuk periode 20 bulan kedepan. Setelah dilakukan perbandingan antara data hasil peramalan dengan data aktual, terdapat kesamaan trend yaitu sejumlah 15 bulan dari total periode yang diramalkan. Sehingga dapat dijelaskan bahwa sebagian besar yaitu $75 \%$ dari hasil peramalan adalah valid.

\subsection{Saran}

Dari hasil yang disajikan seperti di atas, saran yang dapat disampaikan, bahwa dalam meramalkan jumlah kasus penderita demam berdarah dengue (DBD) hanya digunakan metode fungsi transfer single input dengan satu variabel input saja yaitu curah hujan. Tetapi berdasarkan penelitian-penelitian yang sebelumnya terdapat banyak faktor lain yang mempengaruhi jumlah kasus penderita DBD seperti faktor kepadatan penduduk, faktor suhu udara, faktor kelembapan, dan lain sebagainya, sehingga pada penelitian berikutnya dapat digunakan metode yang lebih kompleks seperti fungsi transfer multi input dengan melibatkan lebih banyak variabel input dalam melakukan peramalan jumlah kasus penderita DBD.

\section{DAFTAR PUSTAKA}

[1]. Makridakis, S., Wheel, W.S.C., dan Hyndman, R.J., 1998. Forecasting: Methods and Applications, $3^{\text {rd }}$ ed. John Wiley \& Sons, Inc. New York.

[2]. Profil Kesehatan Kabupaten Jombang Tahun 2016. http://dinkes.jombangkab.go.id/profil-kesehatan

[3]. Sihombing, F.S., Marsaulina, I. dan Taufiq, A., 2011. Hubungan Curah Hujan, Suhu Udara, Kelembaban Udara, Kepadatan Penduduk dan Luas Lahan Pemukiman dengan Kejadian Demam Berdarah Dengue di Kota Malang Periode Tahun 20022011.

[4]. Wei, W.W.S., 2006. Time Series Analysis Univariate and Multivariate Methods $2^{\text {nd }}$ Edition, New York . 